\title{
${ }_{(P S S R}$ \\ Pakistan Social Sciences Review www.pssr.org.pk
}

\section{RESEARCH PAPER}

\section{Militant Religious Extremism: The Way Forward}

Dr. Saqib Khan Warraich ${ }^{1}$ Imran Alam ${ }^{2}$ Fatima Rifat ${ }^{3}$

1. Assistant Professor, Department of Political Science, GC University Lahore, Punjab Pakistan

2. Assistant Professor, University Law College, University of the Punjab, Lahore, Punjab Pakistan

3. Lecturer, Department of History, GC University, Lahore, Punjab, Pakistan

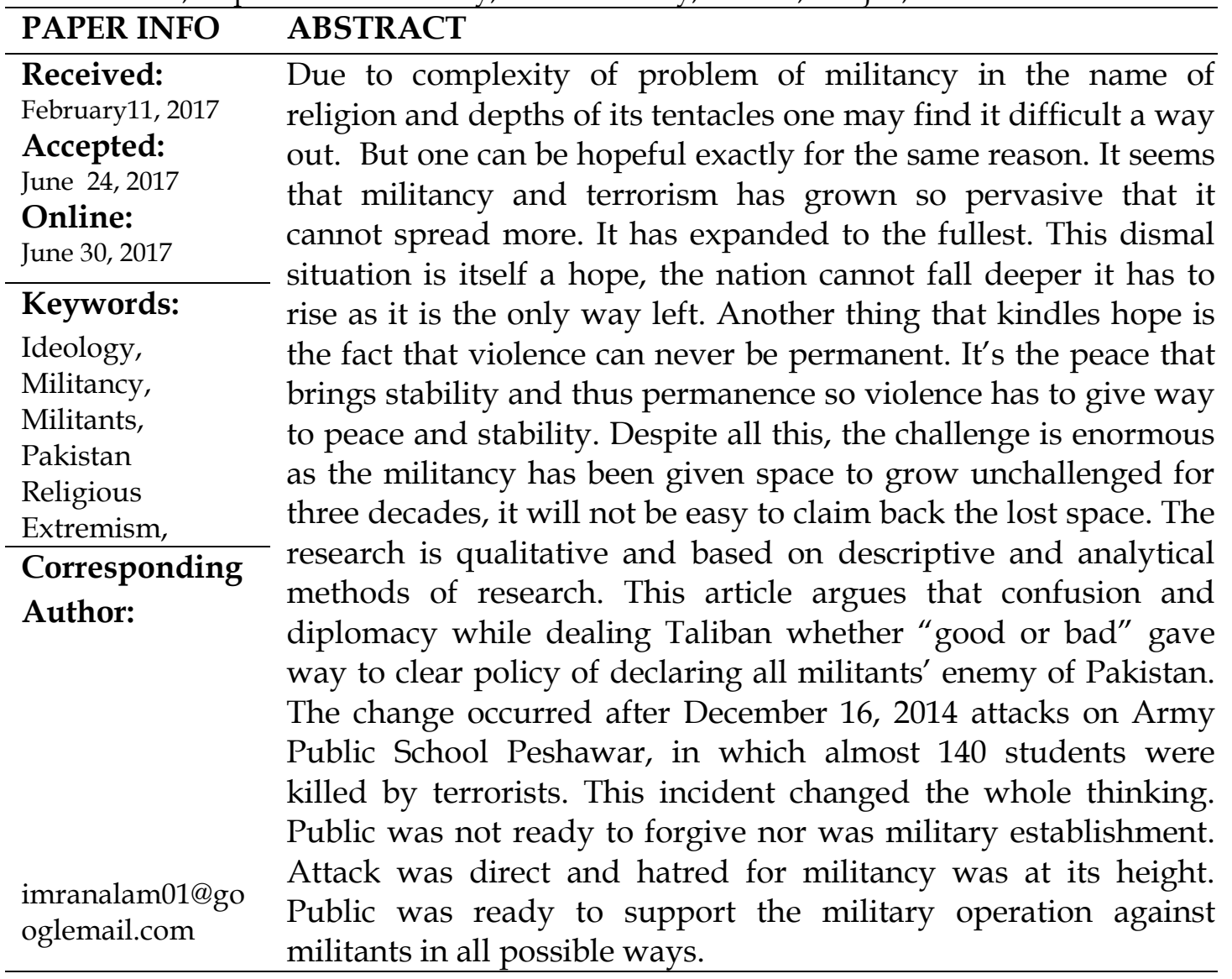

\section{Introduction}

Immediately after APS attack Prime Minister Nawaz Sharif launched National Action Plan which reflected the intention of policy makers that there will be no difference between good or bad militants and all will be dealt with iron first. National Action Plan was charted out with consensus of political and armed forces of Pakistan to fight militancy of all shades in the country (Khattak, 2016). Karachi operation against terrorists, militants, and criminals of kidnapping and extortion 
was launched. People were arrested; proofs were gathered and tried in military courts. As a result, crime rate decreased immediately and a semblance of peace was achieved (Pakistan's Baffling Response to Extremism, 2014). Regarding Zarb-eAzb many militant leaders as well as agents were killed or cross border to Afghanistan. Pakistan Army contained militants, eradicated their strongholds and regaining land lost to terrorists in North Waziristan (Norland, 2015).

With the establishment of military Courts, a message was conveyed that now cases could be registered against religious leaders and result may be significant (Siddiqa, Visible and Invisible, 2015).

There are many intellectuals like Ayesha Siddiqa who supported use of brutal force against these human beasts. Siddiqa says that it's time to spill the blood of terrorists to convey the message of zero tolerance (Siddiqa, Visible and Invisible, 2015).

No counter narrative and no attempts to bring militants to mainstream can persuade them to shun violence. These militants are not only destroying very roots of the state by destroying piece of land and by challenging its internal sovereignty but also by spoiling Pakistan's image as supporter and exporter of militancy in the World. They are targeting innocent citizens of Pakistan and must be eliminated through State force. Pakistan army is the most powerful institution of the State and has the capability to eliminate these elements from the state. Only the will to act should be present at highest level. According to Haider Iqbal "I am not prepared to believe that our armed forces are not competent enough to combat and defeat all brands of terrorists or religious extremists including Taliban"(Khattak, 2016). In order to search for solutions first one has to identify the reasons that led Pakistan towards the menace of terrorism.

\section{Curricula must be revised to cleanse it from biased ideologies}

The education system in Pakistan has deteriorated to the point that it is grooming people who are convinced of their perverted ideologies. After the brutal murder of governor of Punjab, Salman Tasir, by his security guard Mumtaz Qadri, the large majority of nation praised the killer as hero. Lawyers (who were the product of normal education system of Pakistan) garlanded him during his appearance in court. They could not see the treachery of a security guard and they failed to realize that Tasir was taking a courageous stance and was standing on higher moral grounds of trying to safeguard a poor Christian lady charged for blasphemy(Mackey, 2011). Whereas his guard was a hypocrite who killed the person whose security was his responsibility.

The need of the hour is to change curricula taught in schools. Pakistanis have the right to know the truth. No vested interest should be allowed to use text books to achieve its ends. It is not that Pakistani intellectual forgot the reality or absorbed the fallacy found in textbooks; instead their voices were not allowed to reach to the common man. Historians like Mubarik Ali must be encouraged and 
new books without bias against other nations and religions must be taught in schools instead of current policy of teaching ideology of Pakistan in the name of Pakistan studies.

Students must be made acquainted with our pluralistic heritage. According to Ayesha Siddiqa "Extremist values, historically, are the alternative and not mainstream religious discourse"(Siddiqa, Shades of Grey, 2015). It is amazing to know that our Sufi poets were not assured of their morality, and they were not indulged in proving themselves better Muslims. They were tolerant of other sects and religions. But in the present times people got radicalized to such an extent that they are not ready to let people of different sects and religion live side by side with them let alone accepting their (foreign) views.

New teaching methods should also be adopted. No doubt text books are important for students but in higher classes especially after grade $8^{\text {th }}$ students must be encouraged to use other books to find answers to their questions. A probing mind and analytical thinking must be encouraged. By teaching hatred based texts Pakistan has been creating a silent but potential militant force that is not ready to listen to others and that has created a new world of its own, completely aloof of outer world realities.

The perverted thinking would not change as the education system is behind its perpetuation. Students are internalizing hatred written in books and existing in the minds of teachers. The cycle needs to be broken through education system which needs to be thoroughly revised. Curricula, teachers' mindsets as well as teaching methods must be supervised constantly. Student must know that by adopting a radical policy towards the outside world, they are losing the capacity to live in a pluralistic world. They must be taught the danger involved in promoting militancy at state level (Pakistan's current isolation in the world is direct corollary of the policy). They must be taught that due to globalization they cannot create their own truths and live in a world all of their own. They must be taught that the West has attained supremacy through knowledge and not militancy. They can fight the West as well as solve Palestine or Kashmir issues only when their knowledge matches with the knowledge of the enemy (Engineer, Making A Mockery of Jihad, 2010).

\section{Islam must be liberated from the clutches of militants}

Militants like Taliban (or 1980s Mujahidin) used Islam to get support of not only from Afghanistan but all Muslim of the world. While fighting USSR or USA, Mujahidin or Taliban needed money and they got it from Muslim countries in the name of Islam. "Otherwise in the name of Afghanistan nobody will give you money" (Engineer, 2009). Osama Bin Laden and his followers gave reference to Ibu-e-Taymiyyah's Mardin fatwa repeatedly to get support from the Muslims to over throw Saudi monarchy and wage Jihad against US. Ibu Taymiyyah was a product of a particular time and situation. He was born few years after Mongol 
sack of Baghdad with great barbarism. Ibn Taymiyya issued a fatwa sanctioning use of violence against "unjust and authoritarian rulers so as to reestablish the Islamic rule and rule of Sharia (Engineer, Radical Islamism \& Jihad, 2010).

This fatwa became the justification of all violent and senseless acts of terrorists and is being used and universalized by the militants who do not even know Ibu Taymiyyah or his times and circumstances. Ibn-e-Taymiyyah's fatwa was elaborated upon by Syed Qutb whose influence on Al Qaeda is evident.

Sayyed Qutb (1906-66), an Egyptian Muslim Scholar is said to have inspired Osama Bin Laden. According to Lawrence Wright, "Al Qaeda would never have come into existence without influence of Sayyed Qutb" (Valentine, 2008). From 1948-1950 he stayed in USA and examined western life as well as USA policies. He was dead against American support for Israel in 1948. "Immoral and materialist life" in USA made Qutb anti-western and hardened his views regarding implementation of Islam. Qutb joined Muslim Brotherhood on his return to Egypt and mostly remained in jail for opposing the government of Jamal Abdul Nassir from 1954 till his execution by government in 1966 (Valentine, 2008).

During his detention he wrote "Mile Stone" in 1964. The book was translated in different languages and became an inspiration for Muslim militant struggle against western hegemony and western culture and civilization. He called all societies (including Muslim societies) Jahil(ignorant), barbaric and corrupt. Qutb believed in Allah's authority and sovereignty. For him either Islam or state of Jahilia will exist. Struggle between the two is inevitable. Qutb divided world into Dar ul Islam (a place where Islam is dominant) and Dar ul Harb (a place of war). Dar ul Harb is a place where other than Islamic laws prevail even though occupants of that state are Muslims. Qutb was influenced by Ibn-Taymiyya when he said that Muslim rulers are apostate (takfir) if they do not implement Allah's laws and must be opposed. This doctrine was used by militants to kill the Muslims (Berman, 2003).

Qutb's approach was direct and immediate action against takfiri state to snatch power from rulers and establish sharia there thus restoring power to Allah. Qutb challenged Sufi approach of considering Jihad as inner struggle for curbing of evil impulses. He dismissed the principle that Jihad (as many Muslim scholars believe) is a tool for defensive purpose alone. Qutb considers aggressive Jihad as mandatory on all Muslims to establish Sharia and abolish all Satanic forces. He asks Muslims to "kill every leader who look for fame, wealth, power, and social status" (Valentine, 2008).

Qutb was mainly responsible for legalizing killings of the Muslims by the Muslims. His approach to abolish all except Islam is direct and immediate. Militants consider all others as apostate and murder them with impunity. This can be understood from Qutb's quotations of Surah Anfal verse 39 of Holy Quran as "Fight them on until there is no more tumult or oppression and there prevails justice and faith in Allah together and everywhere". Again Qutb used the verse as 
it suited his purpose. The verse was revealed in the context of mischief makers but even against them there would be no fight if they would stop aggression (The Battle of Badr a Proof of the Messenger's Truthfulness ).

The above mentioned verse ordains Muslim to fight not against Muslims or non-Muslim but against mischief makers and aggressors. To fight rising waive of radicalism and militancy, Pakistan is in need of a new narrative, to counter narrative of militant forces. Militants have been using narratives and pompous language to establish their authenticity. According to Eman, Militants use Aristotelian logic in which language is manipulated to stand esoteric. Through this logic Jihad has been reduced to Qital (Slaughter) and only way left to enforce Islam(Hussain, 2013). Ayesha Siddiqua laments the fact that there is no tool for ideological engagement vis-à-vis these elements (Siddiqa, Visible and Invisible, 2015, P-23). To create a new narrative state should come forward. The role of state in this regard is of prime importance owing to the weakness of society.

\section{Policy makers must convey that Pakistan is not a gun for hire}

In 1979 Soviet Union attacked Afghanistan and with this various vested interests became active to work for their objectives. For example, the US was interested in defeat of USSR in Afghanistan. Saudi Arab wanted to popularize its own version of Islam (Wahabism). Military dictator General Zia ul Haq of Pakistan was interested in foreign funds and legitimacy of his rule. As it was in the interests of all three to raise an army of religious militants, it was done with US funding and Saudi tutorials on religious violence (Siddiqa, Contextualising Corruption, 2016) (Zakaria,Saudi Arabia: The Devil We Know,2016). But it was a blunder that General Zia could not realize that they are investing on human minds. As narratives were absorbed by people of Pakistan and guns were provided to them, therefore the grounds for militancy were set in the country. Neither US nor Saudis were affected by militancy as Pakistan was.

\section{The West should be acquainted with the sensitivities of the Muslim World}

Once a unity is achieved regarding a tolerant version of Islam, the Muslim world can take up other sensitive issues like blasphemy with the West. At present it is militants who are projecting themselves as representative of Muslim sensitivities; this concept must be fought vigorously. Acts of terrorism to punish blasphemous acts is not the policy of Muslim World. Such events are not taken as positive and are not helpful to prevent the incidents of blasphemy. These attacks are generally taken as a tool to create violence against the West in the name of blasphemy. To quote Fareed Zakria "...extremist publish unknown cases of attacking Islam to whip up frenzy and hatred followed by violence" (Zakria, A Moment For Moderates,2012).

The world is not realizing the real issue that is by using blasphemous writings or cartoons the West is hurting Muslims religious feelings. For them 
militants are using blasphemy to punish the West so the acts of blasphemy by the Western world would not stop. The only possible way to stop it is through talks. Muslims world leaders should come forward to tell the west about Muslim sensitivities. By this not only militant would be divested of any representative role of the Muslim Ummah but the chances would increase that the West may understand or the western public may be moved in favor of passing a law prohibiting any act of blasphemy (Siddiqa, Confronting the Paris Attacks, 2015).

\section{State must discontinue the policy of using militancy as strategic asset}

Another issue that the Establishment of Pakistan may be considering is regarding fighting good Taliban. Good Taliban are those who are not targeting Pakistan. These militants are active against USA in Afghanistan. Pakistan might be assured of support of good Taliban, like Haqqani group, against India in time of need but the question is what about support of Haqqani network to those groups active against Pakistan (Haqqani, Pakistan's Greatest Enemy is Denial, 2014).

The Scholar has deep contention that in order to eliminate religious militancy Pakistan has to fight militants of all shades. In other words, anyone who has the potential to rise against state of Pakistan must be fought. Questions or argument might be raised by many strategists who are against fighting good Taliban. They generally give reference to the ground realities saying that such rascals are being kept by almost all nations and that they are well in the control of state and only target whenever and wherever required.

The counter argument is if they are under the control of state then the state should go for Madrassa reforms without expecting a backlash, but this is not the situation. In fact, the state considers the interests of militants whenever it formulates a bold policy like Madrassa reforms. Good Taliban might be in line with some policies of the State but they are independent entity. They are not employees of the state and have their own separate interests. What if their interests would be clashed with the interests of Pakistan as happened after the incident of 9/11 (when Pakistan opted to side with USA but all Taliban, good or bad, sided with Al Qaeda)? They targeted Pakistan with their guerrilla tactics. This is the reason why state should fight bad as well as good Taliban. The state should crush the ability of even good Taliban to retaliate the state of Pakistan.

Ayesha Siddiqa enumerates many issues where all militants (whether good or bad) will be together like blasphemy, sectarianism, burden of Muslim Ummah, hatred for the West etc (Siddiqa, Win the War not Just the Battle, 2015).Moreover, all militants are raised for waging Jihad. Their ideological upbringing leads them to act wherever they consider fight necessary for the cause of Islam. One cannot keep them in check to utilize them against India and that too in time when required. According to Hussain Haqqani,

"The problem with ideologically motivated warrior is that their ideology can morph and mutate in directions unacceptable to a pragmatic state. The attacks 
with in Pakistan by Tehrik-e-Taliban Pakistan (TTP) and other militant groups should have made the Pakistani deep state realize some time ago that asymmetric warfare through ideologue is not a reliable military capability...Islamist extremists...hampers Pakistan's evolution as modern state. There will always be extremists who say, "Why are women wearing western dress? Why are girls going to schools? Why are we accepting Shias or Ahmedis or non-Muslims as equal citizens"? (Haqqani, Pakistan's Greatest Enemy is Denial, 2014).

\section{Madrassa Reforms}

As far as Madrassas are concerned, they must be reformed. In Pakistan Madrassas have become the places where youth is being taught to take up arms against the Western world or state of Pakistan (as rules are being dubbed as Western Puppets). For them attacking the West or state of Pakistan is the only way left to revenge for targeting militants (Haqqani, Pakistan's Greatest Enemy is Denial, 2014). The teachings of Madrassas have ruined the lives of many youths.

For Madrassa reforms, Madrassas should be placed under the ministry of Education. The curricula of Madrassas must be thoroughly revised. The books taught in government schools must be read by the students in Madrassas. The teachers should be appointed through a regular system of appointment and they should be given salaries. Madrassas should be forbidden from awarding degrees at their own. The text books taught by Madrassas regarding religious education should be approved by Ministry of Education and should be cleansed from sectarian propaganda.

At present the Madrassas are producing militants ready to kill and be killed for enforcement of archaic regularities in the name of Islam. Instead of Jihadis, Madrassas should be encouraged to produce Muslim scholars and Jurists who are capable of Ijtihad (striving hard to reach at a solution of a modern issue according to Islam) to apply Islamic teachings and principles in modern times and who can understand the flexibility in the nature of Islamic teachings to be applied in changing times.

\section{Government should patronage people with moderate thinking}

It is said that liberals are not active in defeating militant narrative in Pakistan; the reason behind the silence of liberals is the dangers involved. It's very expensive to be a liberal in Pakistan. The best example is that of Governor Punjab Salman Tasir who was a courageous man and enjoying political power but was killed easily and his murder was welcomed by people (as a narrative was built by the militants against him and he was dubbed as blasphemous liable to be killed).

It is a fact that militants have over the years acquired a position where they can influence opinion of Pakistanis. It is not that Pakistanis are dumb who cannot see things or cannot understand realities, the issue is liberal narrative was not 
permitted to flourish. The only narrative permitted was that of militants and people considered it true. Threat to liberals is real(Siddiqa, Price of Idealism, 2015). This is what refrain liberals to be vociferous against forces of darkness. The need of hour is to change this environment of fear and victimization. The state should not only protect but encourage open thinking. Till the date state has failed. It has failed to protect those (like Sabeen Mehmood) who come out with sublime purpose of countering ignorance and militancy. It has failed to protect those who gathered to commemorate death anniversary of Salman Tasir (Siddiqa, Shades of Grey, 2015). A bold step from the state is required to swing the pendulum in favor of liberals. A nod from the state is required and the intellectuals will come with strategies applicable on ground to combat militancy and terrorism.

\section{Conclusion}

As Pakistani society is weak with tribal thinking, it is incapable for an organized action. It can be roused to riots or frenzy in the name of Islam but it cannot stand for the rights of weak or oppressed (Ameer,2016). It is not strong enough to create a new narrative to safeguard itself against radical waves. It will look towards establishment for an action. Under this circumstance state should take initiative and hire Ulema with better understanding of Islam to liberate Islam from the clutches of militants. It is not possible to popularize a narrative to counter militancy without its relevance to religion as only slogans backed by religion will prevent society from getting militarized. Ayesha Siddiqa says:

"The strategy of liberalizing religion from zealots is extremely challenging. Not engaging with religion is not an option because this is the only narrative which sells in society. But building a movement to rationalize religious discourse requires support and greater numbers. This means that the current movement will have to find a way to break out of its current socioeconomic class boundary and reach out to ordinary people" (Siddiqa, Shades of Grey, 2015).

In order to popularize a tolerant version of Islam, Ulema well versed with the teachings of Islam as well as history of Muslim world and current problems faced by the Muslims must be patronized by the state to counter narratives of violence and Jihad promoted by militants in the name of Islam. For this the Ulema must understand the foundations on which militants are building their case.

This discourse may not be effective for the diehard but it can be helpful in bringing those Muslims back in mainstream who are not involved in active warfare. Once the leaders of Muslim world would be agreed on fighting militancy with knowledge, at least another narrative of Islam would be conveyed to the world. Islamic world can allocate resources not only to promote education but also to popularize the narrative of knowledge. They would not be dubbed as US agents as this movement would be indigenous and supported by jurist of Islam. Moreover, this narrative would not absolve the West of its crimes of aggression against the Muslim world, its only giving a new strategy to check the West in its aggression against the Muslims. 
The role of Pakistan in this regard is of utmost importance. Pakistan is the victim of terrorism and militancy. Its population is getting militarized in the name of Islam. Moreover, it always seeks to get a leadership role regarding matters of Muslim Ummah. It is the best opportunity for it to gather the Muslim leaders on a single forum along with eminent Muslim Ulema to popularize the narrative of supremacy of knowledge over violence and snatch the representative role from the militants. The narrative must be followed by concrete steps and formulations of new policies and their implementation in effective manner. The Muslim countries should allocate their best resources towards creating an atmosphere to make new narrative successful as it would save Muslim population from self-destruction and what can be more noble cause before the Muslim world than to safe the Muslim youth from self-destruction. To make the counter militancy narrative successful other strategies should be adopted like political parties of the country can be asked for help. Political parties and their leadership have roots in public and can popularize the message in public that people can be better Muslims if they would work for promotion of education of themselves or their children.

In the context of Pakistan, many political leaders, especially of religious parties, have links with militants. Therefore, the resistance is predictable. For the success the state has to take bold steps. The politicians backing militancy need to be disposed of (Siddiqa, Return of Nationalism, 2014). There is no place for them in new system. It's not a difficult task for the establishment in Pakistan owing to its omnipotent role in all aspects. Media can also be helpful in exposing these politicians. Establishment knows and would have proofs on ground of corruption of these elements and can throw them out of political system. Environment can be made conductive for those who have been making efforts or who are willing to expose futility of an armed struggle against the state or the West.

Media has an important role to play in building and spreading of new narrative. State should ban the militants or their supporters to come on media and present their ideologies. They have had their times when there was only their narrative that was to be published. At present state has banned Altaf Hussain (leader of MQM) speeches or appearance on Television and it is proving very effective. The state can do the same with people who come on TV with the stories of oppression on Muslim world and encouraging Muslim youth to take up arms. This must be stopped immediately. No one should be allowed to promote the ideology of militancy (even indirectly) at any pretext. At the same time print media should be placed under surveillance to stop publications of militant organizations. Special efforts are needed to do this as militants have their dailies, monthlies and quarterlies. The publishers must be fined as well as imprisoned in case of hate based material being published by them. 


\section{References}

Ahmed, S. (2013, 09 27). Post-9/11 Foreign Policy Of Pakistan.

Ali, A. (n.d.). Making a Mockery of Jihad.

Amir, A. $(2015,1211)$. Af,Pak, India: Time to Discard the old Shibboleths. The News

Amir, A. (2016, 01 05). Lost Opportunity. The News .

Amir, A. (2015, 11 06). The News From Kabul.....Bleak. The News .

Amir, A. (2015, 11 17). The West Still not Getting it. The News .

Berman, P. (2003, 03 23). The Philosopher of Islamic Terror. The New York Times .

Blair, G., Fair, C. C., Malhotra, N., \& Shapiro, J. N. (n.d.). Poverty and Support for Militant Politics: Evidence from Pakistan. http://www.sas.upenn.edu/neilmal/poverty.pdf.

Burki, S. J. (2015, 01 12). Economics was the basis of Pakistan's Creation.

Creation and Aim of Pakistan-Two main Views. (2009, 08 14).

Dawood, M. (2006, 05 05). Sufism and Pakistan.

Department for International Development. (2005). http://webarchive.nationalarchives.gov.uk/+/http:/www.didf.gov.uk/pubs/ files/securityforall.pdf.

Engineer, A. A. (2010, 04 16). Ibn Taymiyyah and His Fatwa on Terrorism.

Engineer, A. A. $(2008,04)$. Islam-Muslims and Terrorism. Secular Perspective, pp. 16-30.

Engineer, A. A. $(2008,1013)$. Jihad? But What About Other Verses In Quran?

Engineer, A. A. (2009). Nepal . (Irenees, Interviewer)

Engineer, A. A. (2010, 04 17). Radical Islamism \& Jihad.

Enhanced Partnership with Pakistan Act of 2009 11th Congress (2009-2010). (n.d.). https://www.congress.gov/bill/11th-congress/senate-bill/1707/text.

Fake Quote: Laboratory of Islam By Pakistan Tea House. (2015, 08 18). http:/ / pakteahouse.net/2015/08/18/fake-quote-laboratory-of-islam/.

Fatoohi, L. (n.d.). Myths About The Verse of the Sword. http://www.quranicstudies.com/law/myths-about-the-verse-of-the-sword/. 
Haqqani, H. (2015, 02 02). Comment: A New Foreign Policy Paradigm.

Haqqani, H. (2012, 05 10). How Pakistan Lets Terrorism Fester.

Haqqani, H. (2015, 03 04). Husain Haqqani Calls for Decisive Shift on Kashmir. Dawn .

Haqqani, H. (2014, 07 23). If the Generals have Changed their Mind.

Haqqani, H. (2016). India vs. Pakistan: Why Can't We Just Be Friends? New Delhi: Juggernaut Publishers.

Haqqani, H. (2014, 12 18). Pakistan's Greatest Enemy is Denial .

Haqqani, H. (2014, 05 19). The Slow end of Ideology.

Holbrooke, R. C. (2009). Testimony of Richard C Halbrooke, Special Representative for Afghanistan and Pakistan,. Washington DC.

Hussain, K. (2013). The Militant Discourse.

Khattak, A. (2016, 07 02). Isolation and Isolationalism.

Kruger, A. B., \& Jitka, M. (2003). Education Poverty and Terrorism: Is there a Casual Connection? Journal of Economic Perspective, 17, 119-144.

Mackey, R. (2011, 01 05). Pakistani Lawyers Shower Murder Suspect with Roses . The New York Times.

Mahmood, T. (2013, 03 30). Pakistan was made for all the right reasons and religious extremism was not one of them!

Mansoor, H. (2014, 07 21). Karachi Police Strength Smallest Among Largest Cities' Club. Daily Dawn .

Moral Collapse of a Nation. (2011, 01 08). The Guardian Auditorial .

Mustafa, Z. (2011, 09 20). The Economy after 9/11. Daily Dawn .

Norland, R. (2015, 12 16). Pakistan Military Deals a Blow to Jihadists But Not to Ideology.

Omer, M. (2014, 04 19). Sufism in the Subcontinent.

Pakistan's Baffling Response to Extremism. (2014, 12 22). The New York Times .

Paracha, N. F. (2016, 06 19). Smokers' Coerner: Stories of Violence . Daily Dawn . 
Siddiqua, A. (2015, 04 16). Changign Times. The Express Tribune .

Siddiqua, A. (2015, 01 15). Confronting the Paris Attacks. The Express Tribune .

Siddiqua, A. (2016, 06 08). Contextualising Corruption. The Express Tribune .

Siddiqua, A. (2015, 02 12). Is the Saudi Connection the Main Problem. The Express Tribune.

Siddiqua, A. (2015, 04 30). Price of Idealism. The Express Tribune .

Siddiqua, A. (2014, 12 25). Return of Nationalism. The Express Tribune .

Siddiqua, A. $(2015,0108)$. Shades of Grey. The Express Tribune .

Siddiqua, A. (2015, 07 16). The Ufa 'Uff'. The Express Tribune .

Siddiqua, A. (2015, 02 26). Visible and Invisible. The Express Tribune .

Siddiqua, A. (2015, 01 01). Win the War not Just the Battle. The Express Tribune .

The Battle of Badr a Proof of the Messenger's Truthfulness . (n.d.). al-Islam.org . http:/ / www.al-islam.org/enlighthening-commentary-light-quran-vol6/ section-5-battle-badr-proof-messengers-truthfulness.

Valentine, D. S. $(2008,12$ 14). Sayyed Qutb: Terrorism and the Origins of Militant Islam.

Zakaria, F. (2012, 09 19). A Moment for Moderates.

Zakaria, F. (n.d.). Saudi Arabia: The Devil We Know.

Zakaria, F. (2015, 10 08). The Key to Solving the Puzzle of Afghanistan is Pakistan. Washington Post.

Zelikow, P. (2004). National Commission on Terrorist Attacks upon the United States. New York: The 9/11 Commission Report. 